\title{
Occurrence of Amblyomma longirostre in Ramphastos dicolorus in Southern Brazil
}

\author{
Ocorrência de Amblyomma longirostre em Ramphastos dicolorus no Sul do Brasil
}

\author{
João Fabio Soares ${ }^{\mathrm{I}}$ Claudia Dal Molin Soares ${ }^{\mathrm{I}}$ Miguel Gallio $^{\mathrm{I}}$ Aleksandro Schafer da Silva ${ }^{\mathrm{II}}$ \\ Juliana Pereira Moreira ${ }^{\mathrm{III}}$ Darci M Barros-Battesti ${ }^{\mathrm{IV}}$ Silvia Gonzalez Monteirov
}

\begin{abstract}
The species Amblyomma longirostre Koch, 1844 is poorly known in the state of Rio Grande do Sul. Usually the adult stage could be found on Sphigurus spp. and the immatures on birds (Passeriformes). Although A. longirostre is distributed in the Neotropical region, from Panama to Uruguay, it also occurs in Central America and the United States. The aim of this study was to report that Ramphastos dicolorus Linnaeus 1766 is a new host record for this tick species.
\end{abstract}

Key words: Amblyomma longirostre, Ramphastos dicolorus, new host record.

\section{RESUMO}

A espécie Amblyomma longirostre Koch, 1844 é pouco conhecida no Estado do Rio Grande do Sul. Normalmente a fase adulta pode ser encontrada em porquinhos Sphigurus spp., e as fases imaturas podem ser encontradas em aves (Passeriformes). A. longirostre distribui-se na região neotropical, do Panamá ao Uruguai. Ela também ocorre na América Central e nos Estados Unidos. Este estudo tem como objetivo relatar que Ramphastos dicolorus Linnaeus 1766 é um novo hospedeiro dessa espécie de carrapato.

Palavras-chave: Amblyomma longirostre, Ramphastos dicolorus, novo hospedeiro.
There are more than a hundred species of Amblyomma in the world (HORAK et al., 2002), and half of them occurs in America, from which 33 species are known in Brazil (ONOFRIO et al., 2006). The genus is represented by the biggest and most ornate ticks from the Ixodidae family. Most of species of Amblyomma in adult stage parasitizes large and median mammals, but immatures prefer to feed on small animals. Immature ticks are also found on birds that are rarely parasitized by adult ticks. On the other hand, few species in any stage prefer amphibian and reptiles as host (BARROS \& BAGGIO, 1992; HORAK et al., 2002; BARROSBATTESTI et al., 2006).

Several species of the genus Amblyomma could be potential vector of pathogens mainly because they use more than one host to complete their life cycle (MASSARD \& FONSECA, 2004). According to researchers (LABRUNA et al., 2004), several Rickettsia spp. cause disease in humans and are transmitted by ticks, mites, fleas, or lice. Human could be infected by various Rickettsia spp. depending on geographical location, however the pathogenicity of some Rickettsia spp. to humans is not known. The authors found a Rickettsia strain infecting Amblyomma longirostre Koch, 1844 males collected on porcupine Coendu

\footnotetext{
${ }^{\text {I} C u r s o ~ d e ~ M e d i c i n a ~ V e t e r i n a ́ r i a, ~ U n i v e r s i d a d e ~ F e d e r a l ~ d e ~ S a n t a ~ M a r i a ~(U F S M), ~ S a n t a ~ M a r i a, ~ R S, ~ B r a s i l . ~}$

IIPrograma de Pós-graduação em Medicina Veterinária, UFSM, Santa Maria, RS, Brasil.

IIIZoológico da Universidade de Caxias do Sul, Caxias do Sul, RS, Brasil.

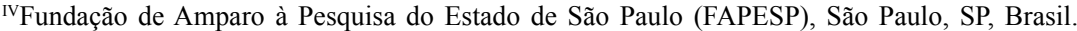

vepartamento de Microbiologia e Parasitologia, UFSM. Faixa de Camobi, Km 9, Campus Universitário, prédio 20, Sala 4232, 97105-900, Santa Maria, RS, Brasil. E-mail: sgmonteiro@uol.com.br. Autor para correspondência.
} 
prehensilis (Linnaeus, 1758) (Rodentia: Erethizontidae) in the state of Rondônia (LABRUNA et al., 2004). The strain of this Rickettsia was designated as strain Aranha. Phylogenetic analysis of a partial ricketsial ompa gene showed that Aranha clustered with 'Rickettsia amblyommii'.

The species A. longirostre is popularly known as 'earring bird tick' because they feed on the neck or close to the eyes of the bird (ARAGÃO, 1936; GUIMARÃES et al., 2001). The adult ticks of this species are common on rodent porcupines but the immatures parasitize birds as well.

The specie A. longirostre was reported in the state of Rio Grande do Sul, Southern Brazil, for the first time in 1997 (OLIVEIRA et al., 1997). It was collected on Coendou villosus (F. Couvier, 1823) from a rural area near to the municipality of Porto Alegre. It was again reported in studies on the same host in the municipality of Pelotas (BRUM et al., 2003). Researchers presented a list of Passeriformes birds infested by $\boldsymbol{A}$. longisrostre from a green area named Parque Copesul de Proteção Ambiental located at the municipality of Triunfo (ARZUA et al., 2005). According to these authors A. longirostre was found on Lathrotriccus euleri Cabanis, Pipraeidea melanonota (Vieillot), Saltator similis Lafresnaye \& d'Orbigny, Synallaxis spixi PL Sclater, Tachyphonus coronatus (Vieillot), Turdus amaurocalinus Cabanis and Turdus subalaris (Seebohm).

In the present study the bird Ramphastos dicolorus Linnaeus, 1766 (Pissiformes: Ramphastidae) popularly known as 'tucano-de-bico-verde' was collected in Antônio Prado municipality (28 51':30”S $\left.51^{\circ} 16^{\prime} 58^{\prime \prime} \mathrm{W}\right)$, State of Rio Grande do Sul by the Environment Patrol (PATRAM). This locality is elevated $658 \mathrm{~m}$ above sea level with an annual average temperature of $16^{\circ} \mathrm{C}$, and annual average rainfall of $1.987 \mathrm{~mm}$. As the bird was stressed it was transported to the Zoo of the Universidade de Caxias do Sul for medical care. After examination the ticks were removed from the skin close to the neck, and preserved in alcohol $70 \%$. All ticks collected were nymphs and they were sent to Instituto Butantan to be identified. The nymphs were identified by optical and scanning electron microscopy and the identification was performed according to the key proposed by KEIRANS \& DURDEN (1998). Two of them were dehydrated for 30 minutes in each of the following concentrations of alcohol: $70 \%, 80 \%, 90 \%$ and $100 \%$ (three times). They were then kept in acetone until undergoing critical point dried. Micrographs were taken in the Laboratory of Electron Microscopy, Museu de Zoologia da Universidade de São Paulo, using a ZEISS/LEO 440 Scanning Electron Microscope.

Among the morphological characteristics $\boldsymbol{A}$. longirostre is the only species of Amblyomma that has lancet hypostome in nymphs (Figure 1.1) and in females. The nymph also presents long gnathosoma with basis capituli triangular (Figure 1.2); scutum with 7-8 large punctuations in the lateral fields and behind of the eyes (Figure 1.3); and the coxae I-IV present short external spurs, obsolete in coxa III as well as the internal spur on coxa I. (Figure 1.4).

The geographical distribution of this tick species includes South of Mexico, Bolivia, Colombia, French Guyana, Panama, Trinidad \& Tobago, Argentina, Paraguay and Venezuela (GUGLIELMONE et al., 2003; ONOFRIO et al., 2006). This specie was also reported in the United States (JONES et al., 1972). In Brazil it was registered in the followings states: Paraná, Pernambuco, Rio de Janeiro, São Paulo, Santa Catarina, Minas Gerais, Goiás, Acre, Amazonas, Pará (GUIMARÃES et al. 2001; ARZUA et al. 2005; STORNI et al. 2005) and Rio Grande do Sul (OLIVEIRA et al., 1997; BRUM et al., 2003; ARZUA et al., 2005). Considering the preference of this species to parasitize porcupine and birds, the nymphs reported as $\boldsymbol{A}$. longirostre on Felis tigrina Schereber, 1775 (Carnivora: Felidae), from the state of Paraná (BARROS \& BAGGIO, 1992) were not A. longirostre but Amblyomma sp. The mistake was observed after comparing nymphs of this and other Amblyomma spp. during the revision of the tick material deposited at the Museu de História Natural Capão da Imbuia (ARZUA et al., 2005).

To the author's knowledge, this is the first report of A. longirostre on $\boldsymbol{R}$. dicolorus as well as for the family Ramphastidae. One concern on this tick species per se is the involvement with the environmental transmission of rickettsial agents. Nevertheless fortunately there is no evidence to support human as host for this tick species (LABRUNA et al., 2004).

\section{ACKNOWLEDGMENTS}

This work was supported in part by the Fundação de Amparo à Pesquisa do Estado de São Paulo by means of the project Fapesp no. 2007-57749-2 and Conselho Nacional de Desenvolvimento Científico e Técnológico $(\mathrm{CNPq})$ by means of Academic career scholarship to DMBB. 

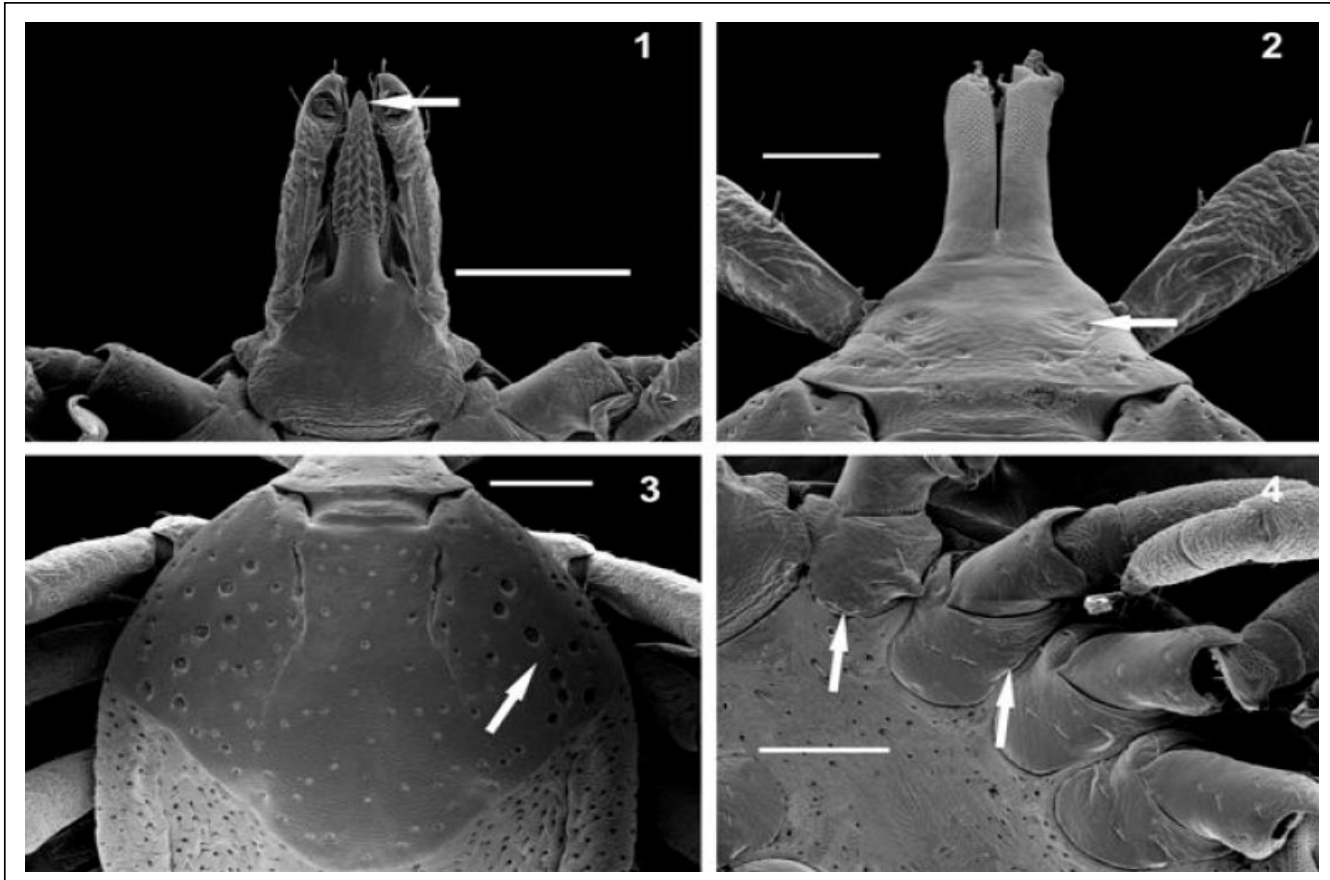

Figure 1 - Amblyomma longirostre nymph. 1. Gnathosoma, ventral view, hypostome lancet (arrowed). 2. Gnathosoma, dorsal view, basis capituli triangular (arrowed). 3. Scutum, with 7-8 large punctuations in the lateral fields and behind of the eyes (arrowed). 4. Idiosoma, ventral view, coxae I-IV with short external spurs, obsolete in coxa III as well as the internal spur on coxa I (arrowed). Scale-bars: $1,300 \mu \mathrm{m} ; 2,120 \mu \mathrm{m} ; 3-4,200 \mu \mathrm{m}$.

\section{REFERENCES}

ARAGÃO, H.B. Ixodida brasileiros e de alguns paizes limitrophes. Memórias do Instituto Oswaldo Cruz, v.31, p.759-844, 1936.

ARZUA, M.A. et al. Catalogue of the tick collection (Acari, Ixodida) of the Museu de História Natural Capão da Imbuia, Curitiba, Paraná, Brazil. Revista Brasileira de Zoologia, v.22, p.623-632, 2005.

BARROS-BATTESTI, D.M. et al. Carrapatos de importância médico-veterinária da região neotropical: um guia ilustrado para identificação de espécies. São Paulo: Vox/ICTTD/Butantan, 2006. 223p.

BARROS, D.M.; BAGGIO, D. Ectoparasites Ixodida Leach, 1817 on wild mammals in the state of Paraná, Brazil. Memórias do Instituto Oswaldo Cruz, v.87, p.291-296, 1992.

BRUM, J.G.W. et al. Ixodidae de mamíferos silvestres atendidos no núcleo de reabilitação da fauna silvestre, UFPel. Arquivos do Instituto de Biologia, v.70, p.211-212, 2003.

GUIMARÃES, J.H. et al. Ectoparasitos de importância veterinária. São Paulo: Plêiade, 2001. 218 p.

GUGLIELMONE, A.A. et al. Ticks (Acari: Ixodida) of the neotropical zoogeographic region. Atalanta Houten: International Consortium on Ticks and Tick-borne Diseases, 2003. 173p.

HORAK, I.G. et al. The Argasidae, Ixodidae and Nuttalliellidae (Acari: Ixodida): a world list of valid tick names. Experimental Applied Acarology, v.28, p.27-54, 2002. Disponível em: http://www.springerlink.com/content/v1830702121468mu/. Doi: $10.1023 / \mathrm{A}: 1025381712339$.

JONES, E.K. et al. The ticks of Venezuela (Acarina: Ixodoidea) with a key to the species of Amblyomma in the Western Hemisphere. Brigham Young University Scince Bulletin. Biological Series, v.17, p.1-40, 1972.

KEIRANS, J.E.; DURDEN, L.A. Illustrated key to nymphs of the tick genus Amblyomma (Acari: Ixodidae) found in the United States. Journal Medical Entomology, v.35, p.489-495, 1998.

LABRUNA, M.B. et al. Molecular evidence for a spotted fever group Rickettsia species in the tick Amblyomma longirostre in Brazil. Journal Medical Entomology, v.41, p.533-537, 2004.

MASSARD, C.L.; FONSECA, A.H. Carrapatos e doenças transmitidas, comuns ao homem e aos animais. A Hora Veterinária, v.135, p.15-23, 2004.

OLIVEIRA, C.M.B. et al. Amblyomma longirostre (Koch, 1844) parasitando ouciço-cacheiro no Rio Grande do Sul. Arquivos da Faculdade de Veterinária, v.25, p.103-104, 1997.

ONOFRIO, V.C. et al. Comentários e chaves para as espécies do gênero Amblyomma. In: BARROS-BATTESTI, D.M. et al. Carrapatos de importância médico-veterinária da região neotropical: um guia ilustrado para identificação de espécies. São Paulo: Vox/ICTTD-3/Butantan, 2006. p.53113 .

STORNI, A. et al. Ácaros de penas e carrapatos (Acari) associados a Turdus albicollis (Aves, Muscicapidae) em uma área de Mata Atlântica da Ilha Grande, Rio de Janeiro, Brasil. Revista Brasileira de Zoologia, v.22, 419-423, 2005.

Ciência Rural, v.39, n.3, mai-jun, 2009. 